\title{
Desmoplastic Small Round Cell Tumor (DSRCT) -Varied Presentation
}

\author{
Tanushri Mukherjee ${ }^{1 *}$, Soma mukherjee ${ }^{2}$ and Rajatdutta ${ }^{3}$ \\ ${ }^{1}$ Department of Pathology, Command hospital Chandimandir, India \\ ${ }^{2}$ Department of Obs Gynae, AIIMS Bhopal, India \\ ${ }^{3}$ Department of surgery, Command hospital, India
}

Submission: September 21, 2017; Published: October 27, 2017

*Corresponding author: Tanushri Mukherjee, Oncopathologist, Department of Pathology Command hospital Chandimandir, India, Email: tanujamukherjee@yahoo.com

\section{Introduction}

Desmoplastic small round cell tumor (DSRCT) is a small round cell tumor usually presents as abdominal lump or omental metastasis [1]. DSRCT is aggressive malignant neoplasm of young male adults and distant metastases occurs at the time of diagnosis [2]. EWS-WT1 fusion protein and $(11 ; 22)(\mathrm{p} 13 ; \mathrm{q} 12)$ translocation, the $\mathrm{N}$-terminal domain of EWS to the C-terminal DNA-binding domain of WT1 is the pathogenesis resulting in an aberrant transcription factor.

Desmoplastic small round cell tumor (DSRCT) was first described in 1989 by [3]. Tumor cells co-express epithelial, mesenchymal and neuronal markers and are thought to originate from a mesothelial or sub mesothelial progenitor cell with the potential to undergo multilineage differentiation. DSRCT despite surgery and chemotherapy yields a poor prognosis and five year survival is $15 \%$ [4].

\section{Case Report}

32 years old serving soldier with history of fullness of abdomen, nausea and poor appetite for 7 days. Known case of Primary sclerosingcholangitis, chronic liver disease with portal hypertension and idiopathic ulcerative colitis. On admissionConscious, afebrile, icterus present. P/A soft nontender, Hepatomegaly present with no splenomegaly, with sluggish bowel sounds. B.P $-108 / 90 \mathrm{mmHg}$, Pulse 100/min, RR 24/ min. CVS-Heard sounds present with no murmur or additional sounds. Initial investigations-Hemoglobin $14.1 \mathrm{gm} / \mathrm{dl}$, TLC 20500 /cumm with $75 \%$ neutrophils, platelets 245000 /cumm. Total Bilirubin $5.1 \mathrm{mg} / \mathrm{dl}$ direct bilirubin $3.0 \mathrm{mg} / \mathrm{dl}$, serum AST/ALT 822 IU/L,AST 730 IU/L, ALP 184 IU/L Urea 93mg/ $\mathrm{dl}$, creatinine $1.3 \mathrm{mg} / \mathrm{dl}, \mathrm{NA} / \mathrm{K} 142 / 4.5 \mathrm{meq} / \mathrm{L} . U S G$ abdomen showed hepatomegaly with coarse echotexture, hemangiomas liver, portal hypertension, thickened colonic wall. Treatment was started on IV fluids, in magnex, injflagyl, injemset, inj albumin, injrantac, injVitK, Tabsulfasalazine, tablets helcal, folate. $\mathrm{Hb}$ 12.2g/dl TLC 28300/cumm, DLC P88L12. Platelets 1.35 / cumm. Total bilirubin $9.3 \mathrm{mg} / \mathrm{dl}$ Direct bilirubin $-5.4 \mathrm{mg} / \mathrm{dl}$. ALT 702IU/L AST 712 IU/L ALP 320 IU/L. Urea(mg/dl) 123mg/dl, Creatinine $(\mathrm{mg} / \mathrm{dl}) 1.9 \mathrm{mg} / \mathrm{dl}$. Subsequently he suffered cardiac arrest. Postmortem examination was conducted. Main gross finding was massively enlarged Liver $3350 \mathrm{gms}$. yellow colored protuberant nodular tumor. Cut surface of the liver showed tumor nodules measuring $7 \times 4 \mathrm{~cm}$, and $5 \times 5 \mathrm{~cm}$. Histologic examination shows small cells that can be round, ovoid or spindled usually grouped in clumps, cords, nests or sheets. These cells contain hyperchromatic nuclei with condensed chromatin and eosinophilic cytoplasm. Mitotic figures are common. The extensive collagenous stroma is characteristic. Microscopically metastasis was noticed in both lungs, intestines and omentum. Figures 1-6. Immuno histochemical markers positivity seen for Epithelial pancytokeratin, epithelial membrane antigen, vimentin, neuron-specific enolase, WT1. Molecular Analysis revealed EWS-WT1 reciprocal translocation on chromosome 22 at $22 \mathrm{q} 12$

\section{Discussion}

DSRCT presents as an aggressive tumor with abdominal mass. The sites of disease include pleura, ethmoid sinuses, scalp, hand, posterior cranial fossa, pancreas, ovary, paratesticular and kidney. Liver metastases are common at diagnosis and relapse; other distant sites include lymph nodes, lung and bones [610]. More than $40 \%$ of patients have distant metastases at the time of diagnosis, mostly located in the liver, lungs, and lymph nodes. The 5-year survival of less than 15\%. Treatment options include surgery, radiotherapy, chemotherapy with or without stem cell transplantation, and recently introduced molecularly targeted therapies [11-16]. Unfortunately there is no standard 
therapeutic regimen described since no modality is clearly superior to any other. Surgery is usually extensive and often includes excision of the omentum, splenectomy and lymph node resections. In addition to surgery and radiation therapy, local control options for DSRCT (particularly metastatic disease) include radiofrequency ablation, gamma knife, cryoablation, embolization and chemoembolization. Chemotherapeutic agents utilized include cyclophosphamide, doxorubicin, vincristine, ifosfamide and etoposide (a combination known as P6 protocol) as well as cisplatin, carboplatin, topotecan, temozolamide, vinorelbine and irinotecan. Although DSRCTs are generally sensitive to chemotherapy, the response is not enough to achieve cure since patients almost invariably relapse. This could potentially be a reflection of the heterogeneity of the cells within the tumor, where a distinct population of cells ("cancer stem cells") that are less sensitive to chemotherapy and radiotherapy possess the ability to self-renew and retain the capacity to regenerate the tumor bulk after it has been eradicated. This represents a highly attractive hypothesis since it could explain tumor behavior and lead to the identification of new targets for more effective therapies. Unlike other small round blue cell tumors like Ewing's sarcoma, such a stem cell has not been yet identified in DSRCTs [17].

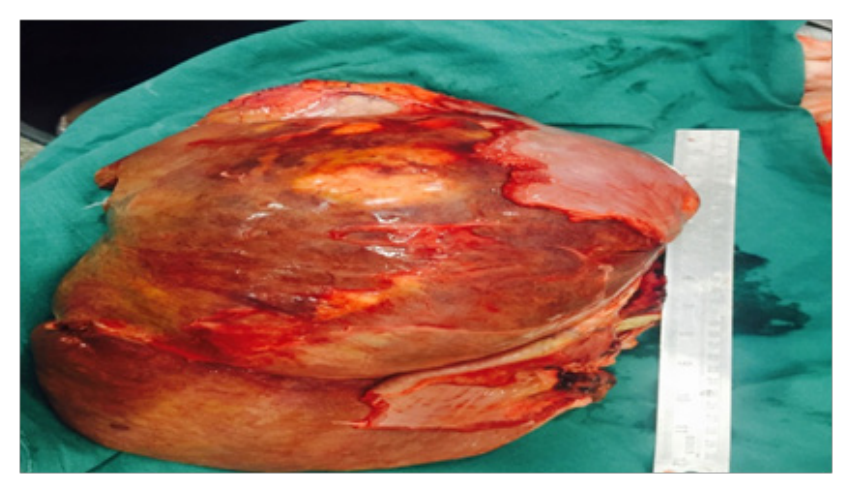

Figure 1: Liver 3350gms. yellow colored protuberant nodular tumor.

Cut surface of the liver showed tumor nodules measuring $7 \times 4$ $\mathrm{cm}$, and $5 \times 5 \mathrm{~cm}$.

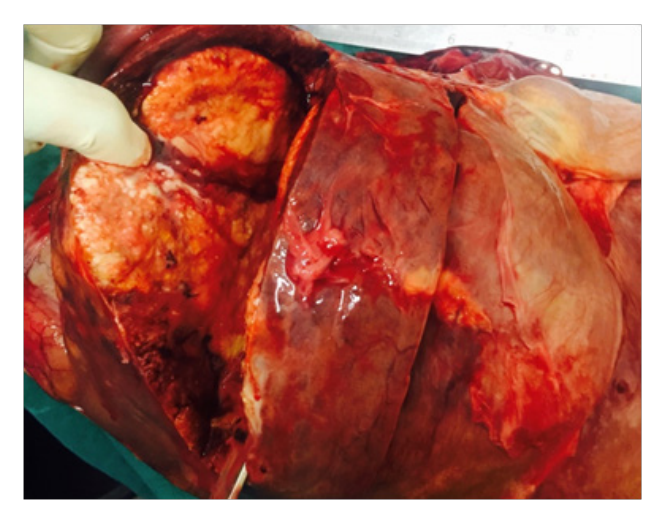

Figure 2:

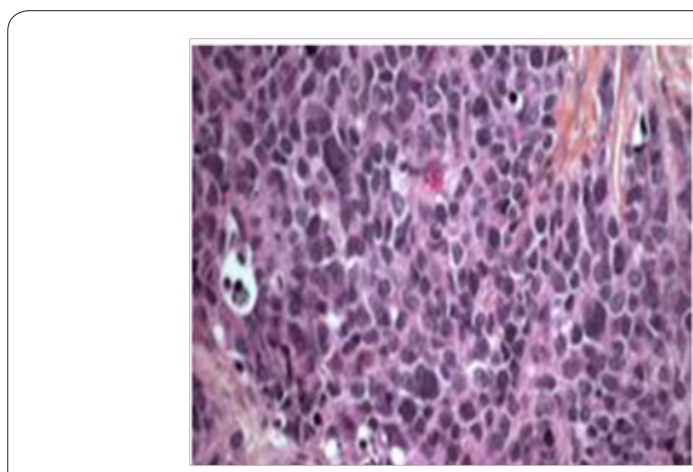

Figure 3: Microphotograph showing small round cell tumor.

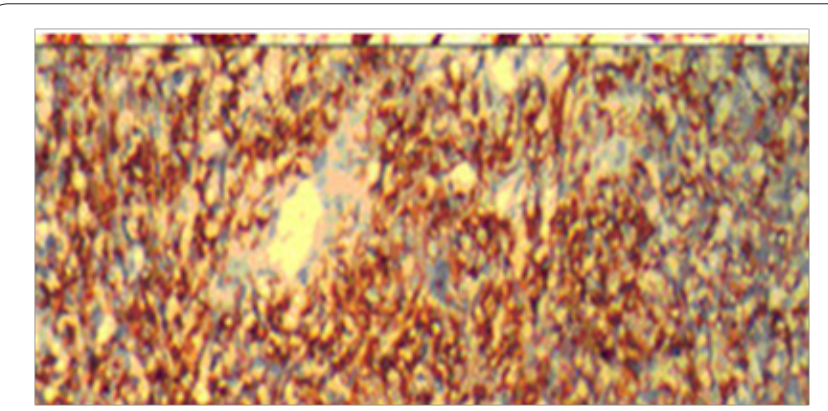

Figure 4: Microphotograph showing immune histo chemistry with WT 1 positivity.

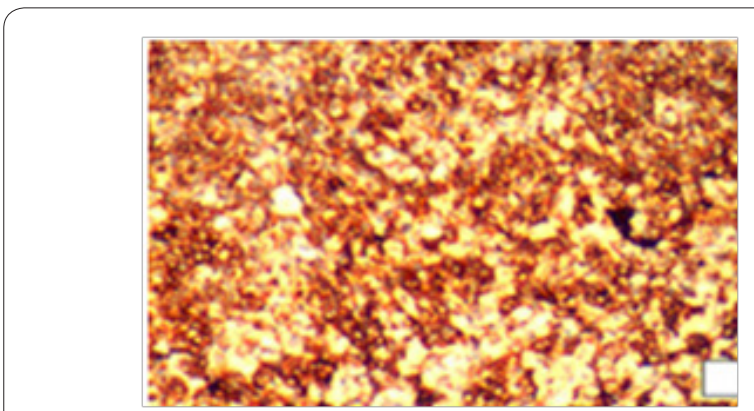

Figure 5: Microphotograph showing pancytokeratin positivity.

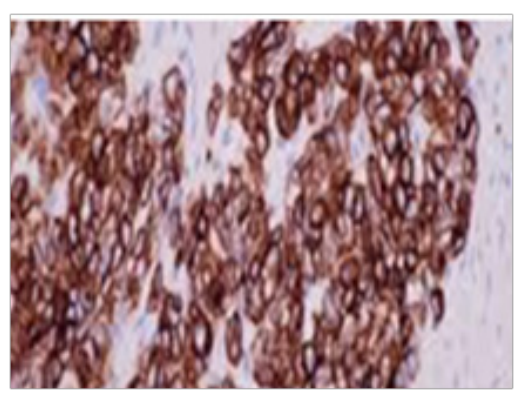

Figure 6: Microphotograph showing Vimentin positivity.

Current treatment modalities are highly toxic, with numerous side effects, and are not sufficiently effective. Recent advances in the understanding of the molecular pathophysiology of DSRCT should lead to the development of effective molecularly targeted therapies with fewer side effects. For example, Leflunomide (SU101) is a platelet-derived growth factor (PDGF) receptor 
inhibitor that acts by blocking PDGF-stimulated receptor auto phosphorylation and subsequent cell-cycle progression. This compound also inhibits dihydroorotate dehydrogenase thus interfering with pyrimidine bio synthesis.

\section{Conclusion}

DSRCT is a highly aggressive small round blue cell tumor of young male adults with a dismal prognosis for which the ideal therapeutic modality is yet to be determined. Current therapeutic approaches remain highly toxic and have not achieved complete disease control. The development of molecularly targeted agents, likely in combination with conventional approaches, could potentially have significant impact on the treatment of this disease.

\section{References}

1. Lae ME, Roche PC, Jin L, Lloyd RV, Nascimento AG (2002) Desmoplastic small round cell tumor: a clinicopathologic, immune histochemical, and molecular study of 32 tumors. Am J SurgPathol 26(7): 823-835.

2. Stuart-Buttle CE, Smart CJ, Pritchard S, Martin D, Welch IM (2008) Desmoplastic small round cell tumour: a review of literature and treatment options. Surg Oncol 17(2): 107-112.

3. Lee YS, Hsiao CH (2007) Desmoplastic small round cell tumor: a clinicopathologic, immunohistochemical and molecular study of four patients. J Formos Med Assoc 106(10): 854-860.

4. Saab R, Khoury JD, Krasin M, Davidoff AM, Navid F (2007) Desmoplastic small round cell tumor in childhood: the St. Jude Children's Research Hospital experience. Pediatr Blood Cancer 49(3): 274-279.

5. Lal DR, Su WT, Wolden SL, Loh KC, Modak S, et al. (2005) Results of multimodal treatment for desmoplastic small round cell tumors. J Pediatr Surg 40(1): 251-255.

6. Eaton SH, Cendron MA (2006) Primary desmoplastic small round cell tumor of the kidney in a 7-year-old girl. J Pediatr Urol 2(1): 52-54.

7. Karavitakis EM, MoschoviM, Stefanaki K, Karamolegou K, Dimitriadis E, et al. (2007) Desmoplastic small round cell tumor of the pleura. Pediatr Blood Cancer 49(3): 335-338.
8. Wang LL, Perlman EJ, Vujanic GM, Zuppan C, Brundler MA, et al. (2007) Desmoplastic small round cell tumor of the kidney in childhood. Am J SurgPathol 31(4): 576-584.

9. Ryan A, Razak A, Graham J, Benson A, Rowe D, et al. (2007) Desmoplastic small round-cell tumor of the pancreas. J Clin Oncol 25(11): 14401442.

10. Chouli M, Viala J, Dromain C, Fizazi K, Duvillard P, et al. (2005) Intraabdominal desmoplastic small round cell tumors: CT findings and clinicopathological correlations in 13 cases. Eur J Radiol 54(3): 438442 .

11. Völker T, Denecke T, Steffen I, Misch D, Schönberger S, et al. (2007) Positron emission tomography for staging of pediatric sarcoma patients: results of a prospective multicenter trial. J ClinOncol 25(34): 5435-5441.

12. Kushner BH, Laquaglia MP, Gerald WL, Kramer K, Modak S, et al. (2008) Soliary relapse of desmoplastic small round cell tumor detected by positron emission tomography/computed tomography. J Clin Oncol 26(30): 4995-4996.

13. Gautam U, Srinivasan R, Rajwanshi A, Bansal D, Marwaha RK (2008) Comparative evaluation of flow-cytometricimmunophenotyping and immunocytochemistry in the categorization of malignant small round cell tumors in fine-needle aspiration cytologic specimens.Cancer 114(6): 494-503.

14. Pohar-Marinsek Z (2008) Difficulties in diagnosing small round cell tumours of childhood from fine needle aspiration cytology samples. Cytopathology 19(2): 67-79.

15. SpuntSL, SkapekSX, Coffin CM (2008) Pediatric nonrhabdomyosarcoma soft tissue sarcomas. Oncologist 13(6): 668-678.

16. Tuveson DA, Fletcher JA (2001) Signal transduction pathways in sarcoma as targets for therapeutic intervention. Curr Opin Oncol 13(4): 249-255.

17. Scharnhorst V, Van der Eb AJ, Jochemsen AG (2001) WT1 proteins: functions in growth and differentiation. Gene 273(2): 141-161.

18. Murphy AJ, Bishop K, Pereira C, Chilton-MacNeill S, Ho M, et al. (2008) A new molecular variant of desmoplastic small round cell tumor: significance of WT1 immunostaining in this entity. Hum Pathol 39(12): 1763-1770.

\section{Your next submission with Juniper Publishers} will reach you the below assets

- Quality Editorial service

- Swift Peer Review

- Reprints availability

- E-prints Service

- Manuscript Podcast for convenient understanding

- Global attainment for your research

- Manuscript accessibility in different formats

( Pdf, E-pub, Full Text, Audio)

- Unceasing customer service

Track the below URL for one-step submission https://juniperpublishers.com/online-submission.php 